\title{
Timahdit sheep production and behavior at three stocking rates in the Moyen Atlas of Morocco
}

\author{
A. EL AICH, L.R. RITTENHOUSE, S. EL KHAMKHAMI, AND T. AIT MHAND
}

\section{Abstract}

Liveweight (LW) changes and behavior of growing rams were measured in 1981, 1982, 1985, and 1986 at the Timahdit Experiment Station in the Middle Atlas, Morocco, at stocking rates of 2.78, 4.17, and 6.67 rams/ha during the growing season. Maximum animal production would have occurred at a stocking rate greater than any imposed in the study in all years except 1982. Increased variable costs should drive stocking rates down while increased selling price would provide an incentive to increase stocking rates. Mean grazing time of animals stocked at light, moderate, and heavy rates was 410, 436, and 504 minutes/day, respectively. Mean resting time was 206, 174, and 106 minutes/day, respectively. Rams under light, moderate, and heavy stocking rates walked 2.1, 2.4 , and $3.1 \mathrm{~km} /$ day, respectively. Diet IVDMD was highest early in the grazing season and lowest in the nongrowing season, and was not affected by stocking rates. Early in the spring, diet diversity was low, increased during active growth, and then declined as the season advanced. Selectivity was lowest when forage was abundant. Dry matter intake varied with season in 1985 but not 1986. There was less opportunity to be adaptive under heavy than under light stocking, resulting in a stocking rate by season interaction in 1986. Under heavy stocking, forage intake $(\mathrm{G} / \mathrm{kg} \mathrm{LW} / \mathrm{min})$ was 61 and $83 \%$ of intake under light and moderate stocking, respectively, and forage intake per $\mathrm{km}$ walked was 71 and $84 \%$, respectively.

\section{Key Words: economies}

Indigenous tribes of different factions and subfactions use Moroccan rangelands in the Moyen (Middle) Atlas for spring, summer, and fall grazing and depend on forage from this region to balance year-long forage supplies. Animals are still a place to store wealth as a liquid asset. As a result, animals are not necessarily sold when selling price is high. Animals are bartered at the souk (market place) to purchase supplies. A myriad of factors drive stocking decisions in the Middle Atlas. Until recently the cost of producing meat in the Middle Atlas was very low. Livestock production in the Middle Atlas is moving toward a market economy. Optimal production of meat and fiber for market should be a concern.

Although records are lacking, production of rangeland forage and animals in the Middle Atlas Region of Morocco is probably far below potential. As an example, forage production inside the Timahdit Experiment Station has far exceeded that outside the Station since 1977 (El Aich et al. 1981). Many factors contribute to the present status of the marginal lands (rangelands). High animal density and frequency of use over extended periods of time are major causes of low rangeland productivity.

The relationship between animal performance and stocking rate is accepted by present day range managers (Hart 1978) and has

\footnotetext{
Authors are associate professor, Institut Agronomique et Veterinaire Hassan II, Rabat, Morocco; professor, Range Science Department, Colorado State University, Ft. Collins; and former Third Cycle Students Institut Agronomique et Veterinaire Hassan II.

The authors are grateful to the Service d'Elevage of Ifrane (Morocco), especially Dr. Aidi, for all the logistical belp provided. Hosni El Mansour and Douma Mohamed, Technicians, IAV Hassan II, assisted in field work and data collection. Acknowledgements are extended to Drs. Makechek, Baily, and Walker for early reviews of the manuscript. The research was funded in part by USAID Minnesota (Morocco) project No. 608-0160 and the Small Ruminant CRSP Project (Morocco).

Manuscript accepted 28 February 1990.
}

been known since antiquity (Gudmondsson 1986). Since the early works of Harlan (1958) and Petersen et al. (1965), animal performance has been explained as a function of stocking rate. The relationship integrates plant and animal factors expressed as animal response over a specified period of time.

We wanted to know what levels of production could be expected from different stocking rates during the growing season and how young rams changed behavior to cope with diminishing forage resources. The specific objectives of this study were: (1) to measure sheep performance under 3 stocking rates, (2) to analyze the effect of costs and selling prices on optimal stocking decisions, and (3) to study sheep behavior in response to grazing pressure.

\section{Methods and Materials}

\section{Study Area}

Studies were conducted at the Timahdit Experiment Station located $18 \mathrm{~km}$ southeast of Azrou and $12 \mathrm{~km}$ northwest of Timahdit in the Middle Atlas Physiographic Province of Morocco (33० $30 \mathrm{~N}$ and $5^{\circ} 10^{\prime} \mathrm{W}$ ). Elevation is about $1,900 \mathrm{~m}$ above sea level. Meteorological data from the Ain Kahla weather station (13 km SW of the Timahdit Station and at the same elevation) approximates the conditions at the Timahdit Station. Average annual precipitation at Ain Kahla is $\mathbf{8 0 0 ~ m m}$. Most precipitation occurs between December and May. Precipitation from December through March comes mostly as snow. Winters are cold with January mean minimum and mean maximum air temperatures of $-2.5^{\circ} \mathrm{C}$ and $9.8^{\circ} \mathrm{C}$, respectively. The hottest month is August with a mean minimum and mean maximum air temperature of $13.6^{\circ} \mathrm{C}$ and $31^{\circ}$ C, respectively.

The landscape of the Timahdit Station is rolling and originated from Jurassic terrain covered by Quaternary bands of basalt. The tall shrubs ( 0.25 to $0.75 \mathrm{~m})$ Adenocarpus boudry Batt \& Maire and Genista pseudopilosa Coss. and the low shrubs $(0.10$ to $0.25 \mathrm{~m})$ Helianthemum croceum (Desf.) Pers. and Thymus algeriensis B. \& $R$. dominate the Region. Herbaceous associations include grasses, such as, Poa bulbosa L., Koeleria splendens C. Presl., Festuca rubra L., F. ovina L., Phleum phleoides (L.) Karsten, Dactylis glomerata L., Stipa lagascae Roem \& Schult, Bromus tectorum L. and Carex divisea Huds.; and forbs such as, Alyssum montanum L., Ranunculus orientalis $\mathrm{L}$. and Vicia lathyroides $\mathrm{L}$. By chance, the amount of browse on the study area is less than that on the remainder of the Station or in the Region.

\section{Handling of Animals}

Growing rams approximately 12 months of age were allotted at random to the 6 paddocks. Initial liveweight was $25-30 \mathrm{~kg}$. Rams grazed the pastures from about 0700 until about $1800 \mathrm{hr}$ daily. Rams were penned and housed at night, at which time they were given water. Paddocks are approximately $1 \mathrm{~km}$ from pens.

\section{Experimental Design}

The 3 stocking treatments were each replicated once within a randomized block design. Five rams were randomly assigned to each of the 3 paddocks in each of 2 blocks. Data were analyzed as a $3 \times 2 \times P$ factorial, i.e., 3 stocking rates, 2 blocks and (P) months. 


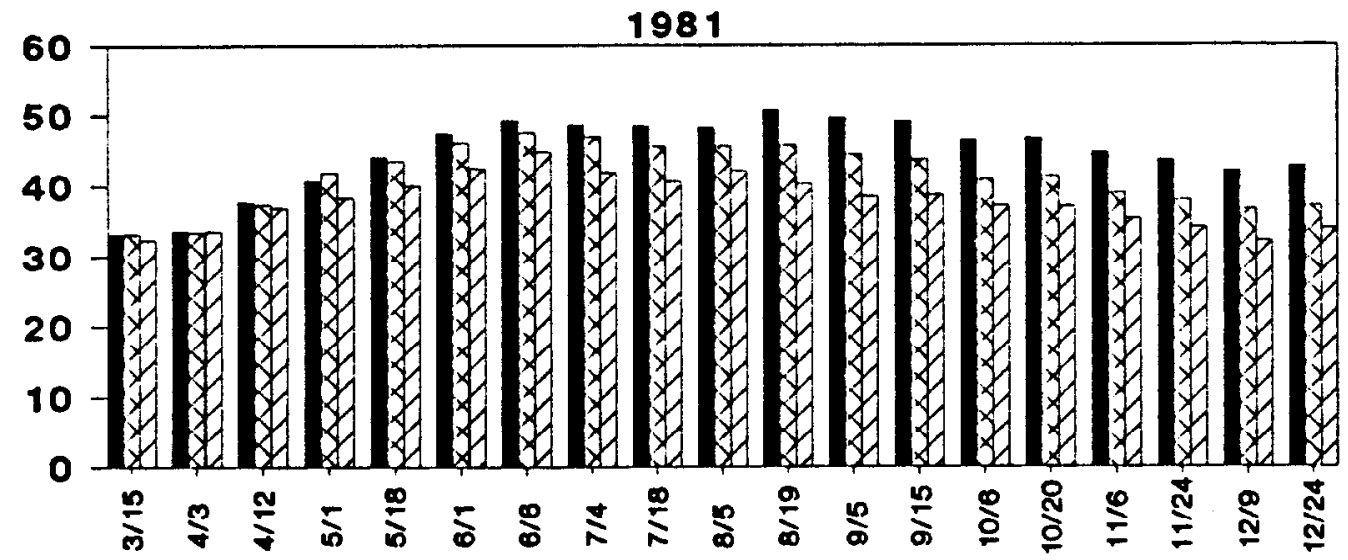

1982

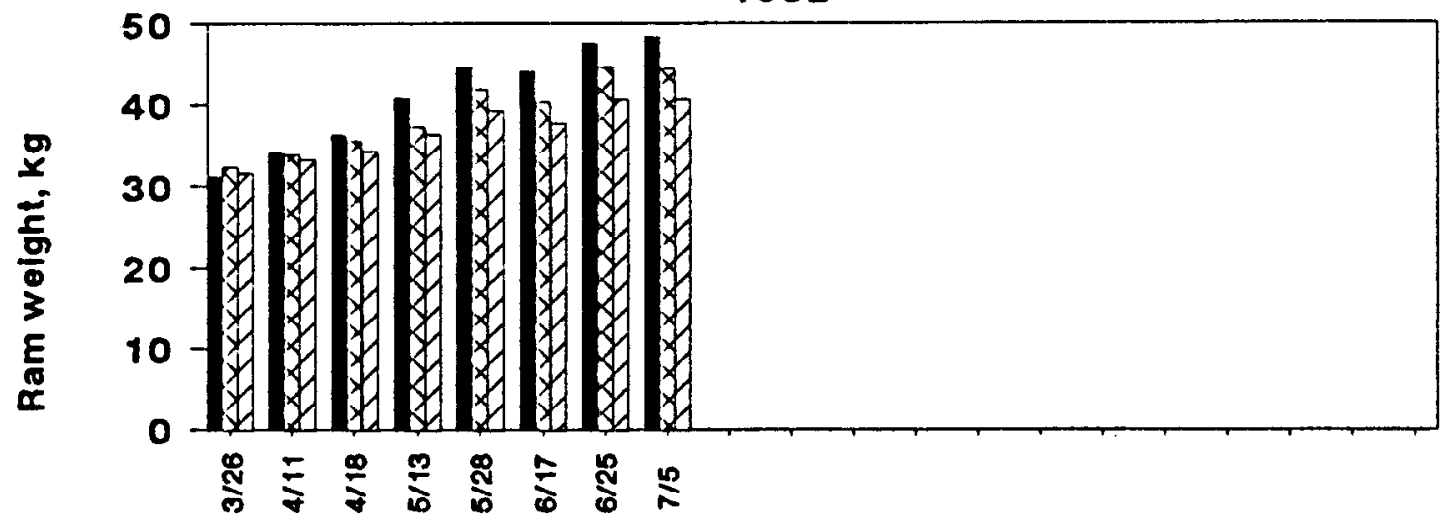

1986

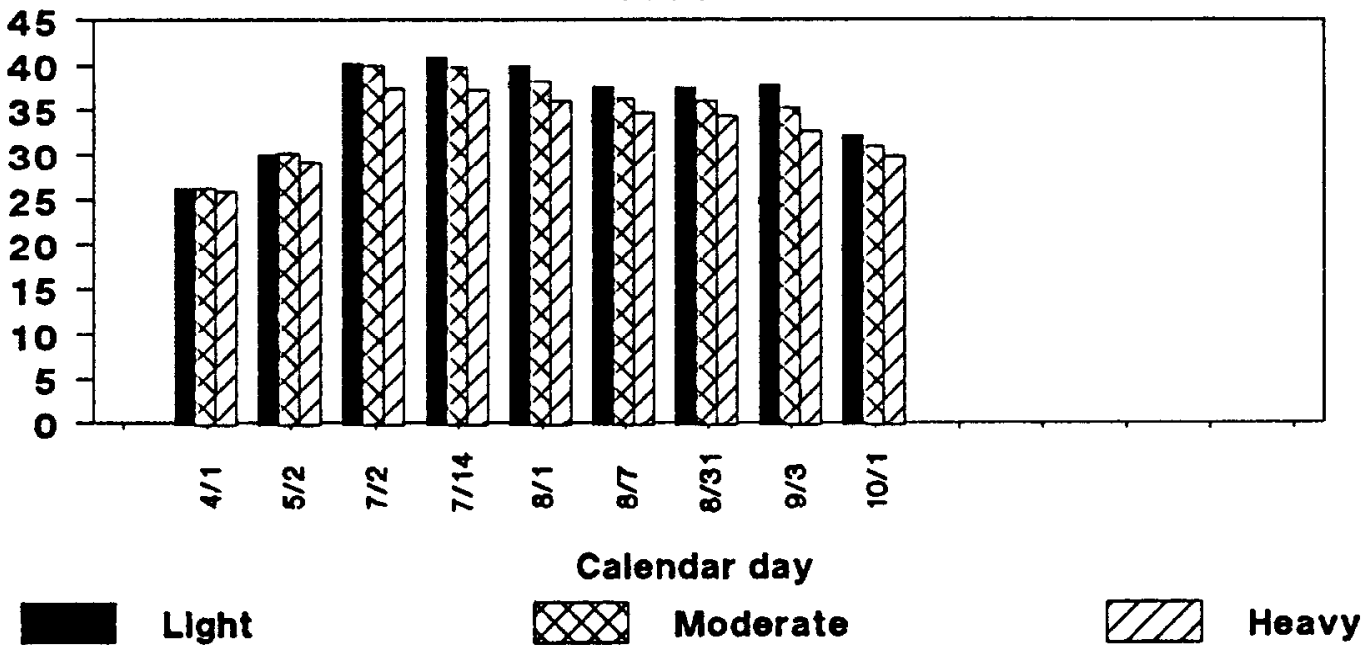

Fig. 1. Liveweight change of yearling rams throughout the 1981,1982 , and 1986 grazing season at the Timahdit Station, Morocco, under light, moderate, and heavy stocking rates.

Years were analyzed separately and mean separations were accomplished with Student-Newman-Keul's multiple range test.

Differences in stocking rate were accomplished by varying paddock size, i.e., $1.80 \mathrm{ha}$ for light, $1.2 \mathrm{ha}$ for moderate, and $0.75 \mathrm{ha}$ for heavy. Three yearling rams had been placed in each paddock, 1977-1980. Five rams were placed in each paddock during our study, resulting in stocking rates of 2.78 (light), 4.17 (moderate), and 6.67 (heavy) rams/ha.

Response variables included: (1) liveweight change, (2) grazing and resting time, (3) qualitative ingestion, including diet diversity and selectivity and in vitro dry matter disappearance (IVDMD), and (4) quantitative ingestion expressed as grams/ram/ $\mathrm{kg}$ liveweight (LW)/day.

\section{Sheep Production Measurements and Analyses}

The dependant variable, cumulative liveweight change per ha (GPH), was calculated as the product of gain/animal and animals/ ha. Analyses of the effect of stocking rate on ram production were based on the average of the last 2 weigh dates that represented the maximum yield/ha from the heavy stocking rate (Fig. 1). The empirical-quadratic fit of animal/ha vs GPH had a positive constant, a biological impossibility. Therefore, the quadratic was forced through zero. The assumption was that stage I of the tradi- 
tional production function (Workman 1986) was absent or not important. The assumption is reasonable since only data for the active growing season were included. This is consistent with the model of Hart (1978). The authors recognize the statistical limitations of fitting the quadratic to 3 data points (even if forced through zero).

Estimates of stocking rate that maximized net return at the end of the active growing season were determined for the years 1981, 1982 , and 1986. Since actual costs and returns were not available, we evaluated the potential effect of changes in marginal costs (the cost of adding 1 more ram/ha) and selling price on net return at different stocking rates. The value of the marginal product (VMP) was the product of the marginal physical product (the increase in $\mathrm{gain} / \mathrm{ha}$ from adding 1 more ram) and selling price, $\mathrm{DH} / \mathrm{kg}$. Fixed costs were not included, because changes in fixed costs influence only the level of return and not optimal stocking levels (Workman 1986). Marginal costs were set at 0,40 , and $80 \mathrm{DH} /$ ha (the exchange rate in 1986 was about $9.00 \mathrm{DH} / \mathrm{US}$ dollar). The value of sheep was set at 5,10 , or $20 \mathrm{DH} / \mathrm{kg}$ liveweight. To simplify calculations, we assumed animals of different liveweights (i.e., from different stocking rates) had the same value/kg. Most animals are sold by the head. In reality, sale price takes into consideration age, sex, size, and body condition. The above costs and selling prices were only intended to cover the range of potential costs and selling prices.

\section{Behavior Measurements and Analyses}

Various measurements have been taken since 1981 to provide evidence of adaptive behavior of Timahdit sheep. Unfortunately, it was not possible to take all measurements in all years. Nevertheless, the system has been monitored nearly continuously since the grazing study was established.

\section{Grazing and Resting Time}

Total time in paddocks was partitioned between grazing and resting by continuous observation during the day. Observations included 7 or 8 consecutive days' observation on 3 focal animals in each paddock approximately monthly during 1985 and 1986 . Animals were penned and housed each night. Animals were moved to the paddocks from the pens as a group.

\section{Distance Walked}

Three animals in each paddock were fitted with digital pedometers in 1985 and 1986 and distance walked was recorded over 7 or 8 consecutive days each month. Pedometers were calibrated at the beginning of each trial. Recordings were corrected for distance to and from pens. Distance was expressed as $\mathrm{km} /$ day.

\section{Ingestion}

\section{Diet Selectivity and Diversity}

Extrusa was collected from 3 esophageally fistulated rams in each replicate for 4 consecutive days during each sampling period. Botanical composition of extrusa collected at 1981 and 1982 served as the basis for calculation of diet diversity and selectivity. Diet diversity was described as the inverse of the Simpson diversity index (Simpson 1949). Selectivity of diets was calculated from the method of Horn (1966).

\section{In Vitro Dry Matter Digestibility of the Diet}

Simulated diets were composited from hand-plucked material similar to that ingested by the animal based on bite count information in 1985 and 1986. In vitro dry matter disappearance (Tilley and Terry 1963) was determined on the simulated diet.

\section{Quantitative Ingestion}

Total voluntary intake of dry matter was determined using the fecal excretion/indigestibility ratio technique. Excretion was mea- sured using total collection bags. Digestibility was estimated from simulated diets using IVDMD. Quantitative intake was determined in 1985 and 1986 and included different segments of the grazing season.

Ratios of ingestion to grazing time $(\mathrm{g} / \mathrm{kg} \mathrm{LW} / \mathrm{min})$ and distance walked $(\mathrm{g} / \mathrm{kg} \mathrm{LW} / \mathrm{km})$ were calculated. These ratios were used as an index of the efficiency with which animals were able to ingest food.

\section{Results and Discussion}

\section{Sheep Performence and Economic Optima}

In all years animals gained weight during the active growing season, but performance declined rapidly as the grazing season progressed. The mean date when animals started to lose weight was negatively related to stocking rate ( \pm SD), i.e., July $10 \pm 17$, July 7 \pm 10 , and June $26 \pm 16$ days for light, moderate, and heavy, respectively. Animals in heavily stocked paddocks lost more $(P<0.05)$ weight than animals in lightly stocked paddocks (Fig. 1). The amount of accumulated weight $/$ ha was less $(P<0.05)$ from heavily than from moderately or lightly stocked pastures after about September. After that date, progressively less cumulative liveweight gain remained on the moderately and heavily stocked paddocks. Forage availability decreased following cessation of growth (Oumekloul 1980, Chergaoui 1981, Chryaa 1982 and Ait Mhand 1987).

Calculated maximum liveweight gain/ ha was some point beyond the highest stocking rate imposed in all years, except 1982. The stocking rate to give maximum liveweight gain/ ha was calculated from the first derivative $\left(b_{1} / 2 b_{2}\right)$ of the quadratic set to zero. This is represented graphically in Figure 2 by the number of rams/ha at which the cost lines converge to the zero-animal value line. Chacon and Stobbs (1976) and others have shown that biting rate increases, bite size decreases, grazing time increases and resting/ rumination time decreases as resources become limiting. As long as the net effect of adaptive behavior can provide adequate nutrition, some positive response from animals is expected. Liveweight gain/ha changes little with changes in stocking rate near the optimal biological stocking rate. The ecological significance is that livestock numbers could have been reduced by 24,22 , and $22 \%$ in 1981,1982 , and 1986 , respectively, while reducing biological production only $5 \%$.

The stocking rate that gives maximum net return is always less than the stocking rate that gives maximum biological output (Fig. 2), because marginal return decreases with each animal added. Optimal stocking rate for different costs and selling prices is the intersection of cost and value lines.

An increase in variable costs shifts optimal stocking rate to a lower level (Fig. 2). Higher livestock prices encourage heavier stocking. It is not intuitively obvious that a decrease in stocking levels would optimize net return, probably because it is more obvious that reductions in animal numbers reduce total gross return.

\section{Animal Behavior \\ Grazing and Resting Time}

Grazing and resting time were affected $(P<0.05)$ by stocking rates (Table 1). In 1985 average grazing time of animals stocked at light, moderate, and heavy rates was 403,430 , and 477 minutes/ day, respectively (Table 1). Concurrently, resting time declined $(P<0.05)$, i.e., 195,163 , and 105 minutes/day, respectively. In 1986, grazing time (resting time) averaged 417 (228), 442 (197), and 531 (110) minutes/day for the respective stocking rates $(P<0.05)$. Total grazing time ranged from 523 minutes in July 1985 to 345 minutes in December 1985. Grazing times were comparable to those reported by Arnold and Dudzinski (1978) and El Aich 
Table 1. Mean graxing and resting time (min) of sheep during selected months in 1985 and 1986.

\begin{tabular}{|c|c|c|c|c|}
\hline \multirow[b]{2}{*}{ Category } & \multicolumn{2}{|c|}{1985} & \multicolumn{2}{|c|}{1986} \\
\hline & $\begin{array}{c}\text { Grazing } \\
\text { time }\end{array}$ & $\begin{array}{c}\text { Resting } \\
\text { time }\end{array}$ & $\begin{array}{c}\text { Grazing } \\
\text { time }\end{array}$ & $\begin{array}{c}\text { Resting } \\
\text { time }\end{array}$ \\
\hline $\begin{array}{l}\text { May } \\
\text { June } \\
\text { July } \\
\text { August } \\
\text { September } \\
\text { November } \\
\text { December }\end{array}$ & $\begin{array}{l}465 \mathrm{c} \\
524 \mathrm{~d} \\
458 \mathrm{c} \\
436 \mathrm{c} \\
392 \mathrm{~b} \\
345 \mathrm{a}\end{array}$ & $\begin{array}{r}139 \mathrm{~b} \\
202 \mathrm{c} \\
210 \mathrm{c} \\
161 \mathrm{~b} \\
89 \mathrm{a} \\
76 \mathrm{a}\end{array}$ & $\begin{array}{l}420 a \\
507 b\end{array}$ & $\begin{array}{l}144 a \\
213 b\end{array}$ \\
\hline \multicolumn{5}{|c|}{ Stocking rates } \\
\hline $\begin{array}{l}\text { Light } \\
\text { Moderate } \\
\text { Heavy }\end{array}$ & $\begin{array}{l}403 a \\
430 b \\
477 c\end{array}$ & $\begin{array}{l}184 \mathrm{c} \\
151 \mathrm{~b} \\
103 \mathrm{a}\end{array}$ & $\begin{array}{l}417 \mathrm{a} \\
422 \mathrm{a} \\
531 \mathrm{~b}\end{array}$ & $\begin{array}{l}228 \mathrm{~b} \\
197 \mathrm{~b} \\
110 \mathrm{a}\end{array}$ \\
\hline
\end{tabular}

Means within a category and year followed by the same letter are not different at $P<0.05$.

(1986). Resting time was also highest in July-August and lowest in November-December. Most rumination probably occurred at night and did not compete with grazing time. Rumination, as well as other activities, were included in resting time. Resting in our study tended to be lower than that reported by Arnold and Dudzinski (1978) or Squires (1981). Grazing and resting times were recorded only during daylight, because animals were penned at night. This experimental protocol limited any possibility of nighttime grazing.

\section{Distance Walked}

Sheep walked an average of $2.55 \mathrm{~km} /$ day in 1985 and 1986 . There were no differences $(P>0.10)$ among seasons in the distance walked, probably because of the small paddock size. Rams under light, moderate, and heavy stocking rates walked $2.1,2.4$, and 3.1 $\mathrm{km} /$ day $(P<0.05)$. Response was the same across all seasons $(P>0.10)$. Distances recorded in this study were about one-half of those recorded by other authors in larger sized pastures (Arnold and Dudzinski 1978, Squires 1981, El Aich and Rittenhouse 1988).

\section{Ingestion}

\section{Qualitative}

Early in the spring diet diversity was low; it increased during the active growth phase and then declined as the season advanced (Table 2). The more abundant and the higher the quality of the

Table 2. Diversity of sheep diets and selectivity of sheep in 1981 and 1982 under 3 levels of stocking throughout the grazing season at the Timahdit Station, Morocco. Diversity and selectivity were based on percentage grass, grasslikes, forbs, and shrubs.

\begin{tabular}{|c|c|c|c|c|c|c|}
\hline \multirow{2}{*}{$\begin{array}{l}\text { Year/ } \\
\text { Month }\end{array}$} & \multicolumn{6}{|c|}{ Stocking rate } \\
\hline & Light & Moderate & Heavy & Light & Moderate & Heavy \\
\hline & \multicolumn{3}{|c|}{ Diversity } & \multicolumn{3}{|c|}{ Selectivity } \\
\hline 1981 & & & & & & \\
\hline $\begin{array}{l}\text { June } \\
\text { July } \\
\text { August } \\
\text { October } \\
\text { November }\end{array}$ & $\begin{array}{l}4.03 \\
3.72 \\
2.62 \\
3.21 \\
3.20\end{array}$ & $\begin{array}{l}3.46 \\
3.94 \\
2.54 \\
2.72 \\
2.81\end{array}$ & $\begin{array}{l}3.30 \\
4.07 \\
2.46 \\
2.62 \\
3.70\end{array}$ & $\begin{array}{l}.96 \\
.53 \\
.68\end{array}$ & $\begin{array}{l}.76 \\
.68 \\
.85 \\
\\
.88\end{array}$ & $\begin{array}{l}.58 \\
.63 \\
.59\end{array}$ \\
\hline \multicolumn{7}{|l|}{1982} \\
\hline $\begin{array}{l}\text { April } \\
\text { May }\end{array}$ & $\begin{array}{l}1.98 \\
2.58\end{array}$ & $\begin{array}{l}2.09 \\
2.23\end{array}$ & $\begin{array}{l}2.25 \\
2.04\end{array}$ & $\begin{array}{l}.84 \\
.85\end{array}$ & $\begin{array}{l}.89 \\
.85\end{array}$ & $\begin{array}{l}.79 \\
.62\end{array}$ \\
\hline
\end{tabular}

resource, the more plant categories were included in the diet, i.e., diversity increased. Mean diet diversity over years tended to be lower with increased grazing pressure, i.e., 3.05, 2.82, and 2.92 under light, moderate, and heavy stocking, respectively. Similar estimates of diversity were reported by El Aich (1986) and Schwartz and Ellis (1981).

The effect of stocking rate on diet composition was reported by Chergaoui (1981) and Chyraa (1982). In their studies grasses composed more than $50 \%$ of the diet at any time of the year. Differences in ingestion of grasses during the growing season among the 3 treatments were usually small. Forbs increased in diets as they became available, but declined with advance in season (Chryaa 1982). Percentage of forbs in the diet ranged from 25 to $5 \%$. With advance in season, diets included more shrubs, regardless of grazing pressure (Chyraa 1982). Although the inclusion of more browse in the diet is well documented at the Timahdit Station (El Aich 1979, Chyraa 1982), the reason for including browse in the diet is unclear. Timahdit sheep are mostly grazers and prefer the herbaceous layer. Harkousse (1982) reported that animals did not change the ingestion of plant parts as grazing pressure increased $(P>0.10)$, but leaves and inflorescences declined $(P<0.05)$ in the diet as the season progressed.

Animals were most selective under heavy stocking rates during the summer (Table 2). This suggests that sheep in heavily stocked paddocks were able to compensate for changes in forage availa bility and maintain high quality diets. The ability to shift diet has potential adaptive significance.

Although animals included different mixes of plants in their diets, diet quality was driven by season and availability. Other studies on this area have shown that as herbaceous plants approach maturity, quality declines rapidly. Harkousse (1982) found that between May and June 1981 crude protein declined $28 \%$ and in 1982, 16\%. In 1981 crude fiber (CF) increased by 35\% between May and June. In 1982 CF increased 34\% but changes occurred earlier, i.e., sometime between March and May. This was reflected in cessation of ram growth and subsequent loss of liveweight (Fig. 1).

Ram diets in the current study were highest in IVDMD in the early grazing season and lowest in the nongrowing season

Table 3. Percent in vitro dry matter digestibility (IVDMD) of simulated sheep diets during 1985-86 at the Timahdit Station, Morocco.

\begin{tabular}{lc}
\hline \hline Category & Digestibility (IVDMD) \\
\hline Months & $\%$ \\
1985 & $56.92 \mathrm{c}$ \\
June & $57.07 \mathrm{c}$ \\
July & $49.18 \mathrm{~b}$ \\
August & $57.05 \mathrm{c}$ \\
September & $53.08 \mathrm{c}$ \\
November & $44.77 \mathrm{a}$ \\
December & \\
1986 & $58.15 \mathrm{~b}$ \\
May & $55.78 \mathrm{a}$ \\
July & \\
Stocking rates & \\
1985 & \\
Light & \\
Moderate & $51.57 \mathrm{a}$ \\
Heavy & $52.25 \mathrm{a}$ \\
1986 & $55.21 \mathrm{~b}$ \\
Light & \\
Moderate & $57.10 \mathrm{a}$ \\
Heavy & $56.60 \mathrm{a}$ \\
\hline
\end{tabular}

Means followed by the same letter within the same year do not differ at $P>0.05$. 
$(P<0.05)$ (Table 3). The IVDMD was affected $(P>0.05)$ by stocking rates in 1985, but not in 1986. Diet quality at any time is dependent on phenological stage of plant growth and environmental growing conditions (Van Soest 1982). Animals have the opportunity to include more browse in the diet with advance in season (El Aich et al. 1980) which enhances diet protein content (Harkousse 1982), but the energy content of browse is low as reflected in IVDMD (Table 3).

\section{Quantitative}

In 1985, the interaction of season by stocking rates was significant $(P<0.05)$ on daily ingestion expressed as $\mathrm{g} / \mathrm{kg} \mathrm{LW} /$ day. Sheep were able to ingest proportionately more dry matter under all conditions at the light than at other stocking rates. Animals had less opportunity to respond to varying conditions at the heavy stocking rate. Ingestion varied $(P<0.05)$ among months in 1986 and averaged 37.6 and $27.4 \mathrm{~g} / \mathrm{kg} \mathrm{LW} /$ day for May and July, respectively. These findings are similar to Harkousse (1982) and El Aich (1986). The amount of herbaceous material on offer, especially grasses, ultimately may limit intake. Ingestion is less constrained on high than on low quality pastures.

Table 4. Ingestion rate of sheep stocked at 3 rates during 1985 and 1986 at the Timahdit Station. Intake was expressed as g/kg liveweight (LW)/day.

\begin{tabular}{|c|c|c|c|}
\hline \multirow[b]{2}{*}{ Month } & \multicolumn{3}{|c|}{ Stocking rates } \\
\hline & Light & Moderate & Heavy \\
\hline \multicolumn{4}{|c|}{$\cdots \mathrm{g} / \mathrm{kgLW} /$ day $\cdots$} \\
\hline $\begin{array}{l}\overline{\text { June }} \\
\text { July } \\
\text { August } \\
\text { September } \\
\text { November } \\
\text { December }\end{array}$ & $\begin{array}{l}43.08 \mathrm{c} \\
31.08 \mathrm{ab} \\
22.92 \mathrm{a} \\
41.70 \mathrm{bc} \\
24.90 \mathrm{a} \\
24.24 \mathrm{a}\end{array}$ & $\begin{array}{l}26.91 \mathrm{a} \\
23.42 \mathrm{a} \\
22.59 \mathrm{a} \\
38.90 \mathrm{bc} \\
25.07 \mathrm{a} \\
23.81 \mathrm{a}\end{array}$ & $\begin{array}{l}22.07 \mathrm{a} \\
25.13 \mathrm{a} \\
22.50 \mathrm{a} \\
35.60 \mathrm{abc} \\
28.41 \mathrm{a} \\
24.09 \mathrm{a}\end{array}$ \\
\hline \multicolumn{4}{|l|}{1986} \\
\hline $\begin{array}{l}\text { May } \\
\text { July }\end{array}$ & $\begin{array}{l}37.52 \mathrm{a} \\
29.66 \mathrm{a}\end{array}$ & $\begin{array}{l}39.03 a \\
26.96 a\end{array}$ & $\begin{array}{l}36.23 \mathrm{a} \\
25.66 \mathrm{a}\end{array}$ \\
\hline
\end{tabular}

Means within each year followed by the same letter are not different at $P<0.05$.

\section{Indices of Optimal Use}

Dry matter ingested per minute of grazing time in 1985 varied $(P<0.05)$ with grazing pressure and averaged $.079, .063$, and .053 $\mathrm{g} / \mathrm{kg} \mathrm{LW} / \mathrm{min}$ of grazing time for light, moderate, and heavy stocking rates, respectively (Table 5). However, ingestion rate of rams in 1986 was similar $(P>0.05)$.

Table 5. Ratio of ingestion of sheep at the Timahdit Station per $\mathrm{kg}$ liveweight per day and grazing time (min) or distance walked (km). Animals were stocked at 3 rates. Ratios were determined for 6 dates in 1985 and 2 dates in 1986.

\begin{tabular}{lccl}
\hline \hline & \multicolumn{3}{c}{ Stocking rates } \\
\cline { 2 - 4 } Month & Light & Moderate & Heavy \\
\hline 1985 & & & \\
$\mathrm{~g} / \mathrm{kgLW} / \mathrm{km}$ & $15.90 \mathrm{~b}$ & $11.59 \mathrm{ab}$ & $8.68 \mathrm{a}$ \\
$\mathrm{g} / \mathrm{kgLW} / \mathrm{min}$ & $0.079 \mathrm{~b}$ & $0.063 \mathrm{a}$ & $0.057 \mathrm{a}$ \\
1986 & & & \\
$\mathrm{~g} / \mathrm{kgLW} / \mathrm{km}$ & $14.60 \mathrm{a}$ & $13.66 \mathrm{a}$ & $9.88 \mathrm{a}$ \\
$\mathrm{g} / \mathrm{kgLW} / \mathrm{min}$ & $0.085 \mathrm{a}$ & $0.075 \mathrm{a}$ & $0.060 \mathrm{a}$ \\
\hline
\end{tabular}

Means within each row and followed by the same letter do not differ at $P<0.05$.
In 1985 , ingestion rate $/ \mathrm{kg} \mathrm{LW} / \mathrm{km}$ walked (Table 5) under heavy stocking was $55 \%$ of the ingestion rate by sheep under light stocking. During spring of 1986 , the magnitude of differences among stocking rates was similar and not significant (Table 5). Since grams ingestion/meter walked declined linearly from light to heavy stocking rates, we assume the lightest stocking rate may also have limited rate of ingestion.

\section{Conclusion}

Ultimately, one must conclude that economics probably have little to do with stocking decisions in the Middle Atlas. In most years adding animals, at least up till early summer, resulted in a nearly additive increment of additional gain/ ha. However, by fall animal liveweight change becomes negative. The light stocking rate produced the most liveweight by late fall. The influence of stocking rate on yearling lamb performance may be greater than on that of nursing lambs, because nursing lambs would draw on the ewes' reserves through her milk production. Another problem is that these rangelands are used from late February to late November. Therefore, stocking rates would need to be much lower to ensure available resources, regardless of quality.

The impact of changes in variable cost and selling price had some influence on level of return, but differences were probably not large enough to influence stocking decisions. The only variable with management implications was the time during the growing season when animals started to lose weight and yield/ ha started to decline.

The implication is that stocking decisions in this area of Morocco should be based more on sustainability of the resource (i.e., maintaining or improving the vegetation diversity and productivity and preventing soil erosion) than on animal yield or profitability. Where animals are grazed in common, many variables other than economic factors determine the livestock operators response to risk. Not all variables and their impact are known.

This study was based on growing rams. This presents a problem in extrapolation of the data to actual pastoralist activities in the region. Extension of this data must be done with caution, since the statistical model is a fixed model. These persons often own mixes of different kinds and classes of animals. In order to use these results for initial "best estimates" of optimal stocking the operator should compare such things as rangeland productivity, exchange ratios of animals of different classes or production states, efficiency of spatial use, herder motivation, etc. Suitable exchange ratios between growing rams and females producing singles or twins, growing ewes, or empty females have not been determined. Forero et al. (1989) showed that steers could be substituted for cow-calf pairs on a weight:weight basis. A similar ratio may apply to producing sheep.

\section{Literature Cited}

Ait Mhand, T. 1987. Comportement alimentaire des ovins sous different niveaux de charge. Memoire de fin d'etude de l'Institut Agronomique et Veterinaire Hassan II, BP 6202, Rabat, Maroc.

Arnold, G.W., and M.L. Dudzinski. 1978. Ethology of free-grazing domestic animals. Elsevier.

Chacon, E., and T.M. Stobbs. 1976. Influence of progressive defoliation of a grass sward on the eating behavior of cattle. Aust. J. Agr. Res. 27:709-727.

Chergaoui, A. 1981. Etude des preferences alimentaires des ovins et de la vegetation sous different niveaux de charge a la Station Pastorale de Timahdit. Memoire de fin d'etude del'Institut Agronomique et Veterinaire. Hassan II. BP 6202, Rabat, Maroc.

Chyraa, A. 1982. Etude de l'impact de la season et de la charge animal sur les preferences alimentaives des ovins Timahdit. Memoire de fin d'etude de l'Institut Agronomique et Veterinarire. Hassan II. BP 6202, Rabat, Maroc. 
El Aich, A., M. Atiqui, and D. Himeur. 1981. Le point sur les recherches menees a la Station Pastorale de Timahơit de 1978 a 1980 . Homme Terre et Eaux. 44:71-78.

El Aich, A. 1986. Ingestive behavior of herded and free-grazing Timahdit sheep. Ph.D. Diss. Colorado State Univ., Ft. Collins.

El Aich, A., and L.R. Rittenhouse. 1988. Herding and forage ingestion by sheep. Appl. Anim. Behav. Sci. 19:279-290.

Forero, L., L.R. Rittenhouse, and J.E. Mitchell. 1989. A cow-calf vs yearling substitution ratio for shortgrass steppe. J. Range Manage. 42:

Gudmundsson, 0.1986 . Grazing research at Northern latitude, ed. Olafur Gudmundsson. Nato ASI Series. Ser. A: Life Sciences, Vol. 108, Pleum.

Harkousse, M. 1982. Etude de la charge et le temps sur lavaleur nutritive de la ration et les quantiles ingerees par les ovins a la Station Pastorale de Timahdit. Memoire de fin d'etude. Institut Agronomique et Veterinaire. Hassan II. BP 6202. Rabat.

Harlan, J.R. 1958. Generalized curves for gain per head and gain per ha in rate of grazing studies. J. Range Manage. 11:140-147.

Hart, R.H. 1978. Stocking rate theory and its application to grazing on rangelands. First Int. Rangel. Congr. 547-550.
Hom, H.S. 1966. Measurement of the overlap in comparative ecological studies. Amer. Nat. 100:419-424.

Oumekloul, A. 1980. Effet de la charge sur la vegetation et les performances des ovins a la station pastorale de Timahdit. Memoire de fin d'etude de l'Institut Agronomique et Veterinaire Hassan II, BP 6202, Rabat, Maroc.

Peterson, R.G., H.L. Lucas, and G.O. Mott. 1965. Relationship between rate of stocking and per animal and per acre performance on pasture. Agron. J. 57:27-30.

Schwartz, C.C., and J.E. Ellis. 1981. Feeding ecology and niche separation in some native and domestic ungulates on the shortgrass prairie. J. Appl. Ecol. 18:343-353.

Simpson, E.M. 1949. Measurement of diversity. Nature (London), 163:688.

Squires, V.R. 1981. Livestock management in the arid zone. Inkata Press. Melbourne.

Tilley, R.A., and J.M. Terry. 1963. A two-stage technique for in vitro digestion of forage crops. J. Brit. Grassl. Soc. 18:104-

Van Soest, P.J. 1982. Ecology of the ruminant. O. \& B. Books, Corvallis, Ore.

Workman, J. 1986. Range economics. Macmillan Publ. Co. 